\title{
VARIABILITY IN MORPHOLOGY OF MICROSPHAERA ALPHITOIDES GRIFFON ET MAUBL. IN POLAND
}

\author{
KRZYSZTOF UFNALSKI, KRYSTYNA PRZYBYŁ \\ Institute of Dendrology, Polish Academy of Sciences \\ Parkowa 5, 62-035 Kórnik, Poland \\ e-mail: krzys@man.poznan.pl
}

(Received: January 28, 2004. Accepted: March 30, 2004)

\begin{abstract}
The aim of this study was to verify descriptions of the morphology of the fungus responsible for powdery mildew on oak leaves of nursery seedlings and of young trees in forest stands. Infected, fully developed leaves from apical parts of stems of Quercus robur or Q. petraea were collected in two national parks and in six forest districts in Poland. The taxonomic characteres of all specimens were generally consistent with those given in keys for $M i$ crosphaera alphitoides. However, the limoniform shape of conidia, characteristic of two sites (nurseries), has not been found in available synopses. Limoniform conidia were significantly longer and wider than others. A great variety of forms of mycelium on leaves were observed. The mycelium appeared in three forms: (1) floccose or felted oval patches (always with yellow or brown discoloration), (2) faveolate oval patches (often with yellow or brown discoloration), and (3) felted or mealy mycelium along veins (rarely with discoloration). Mycelium without limoniform conidia appeared in all forms, while mycelium with limoniform conidia appeared only in the form of patches, always causing leaf discoloration.
\end{abstract}

KEY WORDS: Microsphaera alphitoides, Quercus robur, Quercus petraea, taxonomy.

\section{INTRODUCTION}

Microsphaera alphitoides Griffon et Maubl. occurs mainly on Quercus species and causes powdery mildew. Among the European oaks, $Q$. robur $\mathrm{L}$. is very susceptible and Q. petraea Liebl. is less so (e.g. Ayres 1976). M. alphitoides is known to cause serious damage to nursery plants and young trees, especially newly planted in forest. In the case of older trees, it plays a part in oak decline, which is affected by many factors, e.g. summer drought, winter and spring frost, and various fungi and insects in many areas of Europe (e.g. Thomas et al. 2002). Some authors have recorded the occurrence of another powdery mildew of leaves of Quercus spp. (including $Q$. robur and $Q$. petraea), caused by $M$. hypophylla Nevodovskii (syn. M. sylvatica Vlasov), which is characterized by a lower pathogenicity (Braun 1995 and Sałata 1985). In Poland the occurrence of $M$. hypophylla was noted only about 20 years ago in the eastern and central part of the country (Sałata 1985). Generally, very little information is available on the taxonomy and distribution of these two taxa in Europe.

The aim of this study was to verify descriptions of the morphology of the fungus responsible for powdery mildew on oak leaves collected from nursery seedlings and of young trees in forest stands.

\section{MATERIAL AND METHODS}

\section{Sampling methods}

Infected, fully developed leaves from apical parts of stems of Quercus robur or Q. petraea were collected from early June till late October 2003 in two national parks (NPs) and in six forest districts (FDs). The plants were: (1) 2-year-old nursery seedlings, growing in the Chełm FD (eastern Poland), Łopuchówko FD (central Poland), and in the Wielkopolska and Wolin NPs (central and northern Poland, respectively); and (2) 5-20-year-old trees growing in the Nowogard FD (eastern Poland), Karczma Borowa and Babki FDs (central Poland), Mrągowo FD (northern Poland), and in the Wielkopolska and Wolin NPs (Fig. 1, Table 1). The material was transported directly to the laboratory in a plant press.

\section{Taxonomic investigations}

The observations were made directly after collection of leaves. In each specimen, measurements of the length and width of conidia (about 30), ascospores (about 20), and/or diameter of cleistothecia (about 25, found only on four sites) were made for randomly selected leaves. Conidiophores were rarely observed in microscopic preparations. In total, 604 conidia, 107 cleistothecia, 80 ascospores and 57 conidiophores were measured. In the case of investigations 


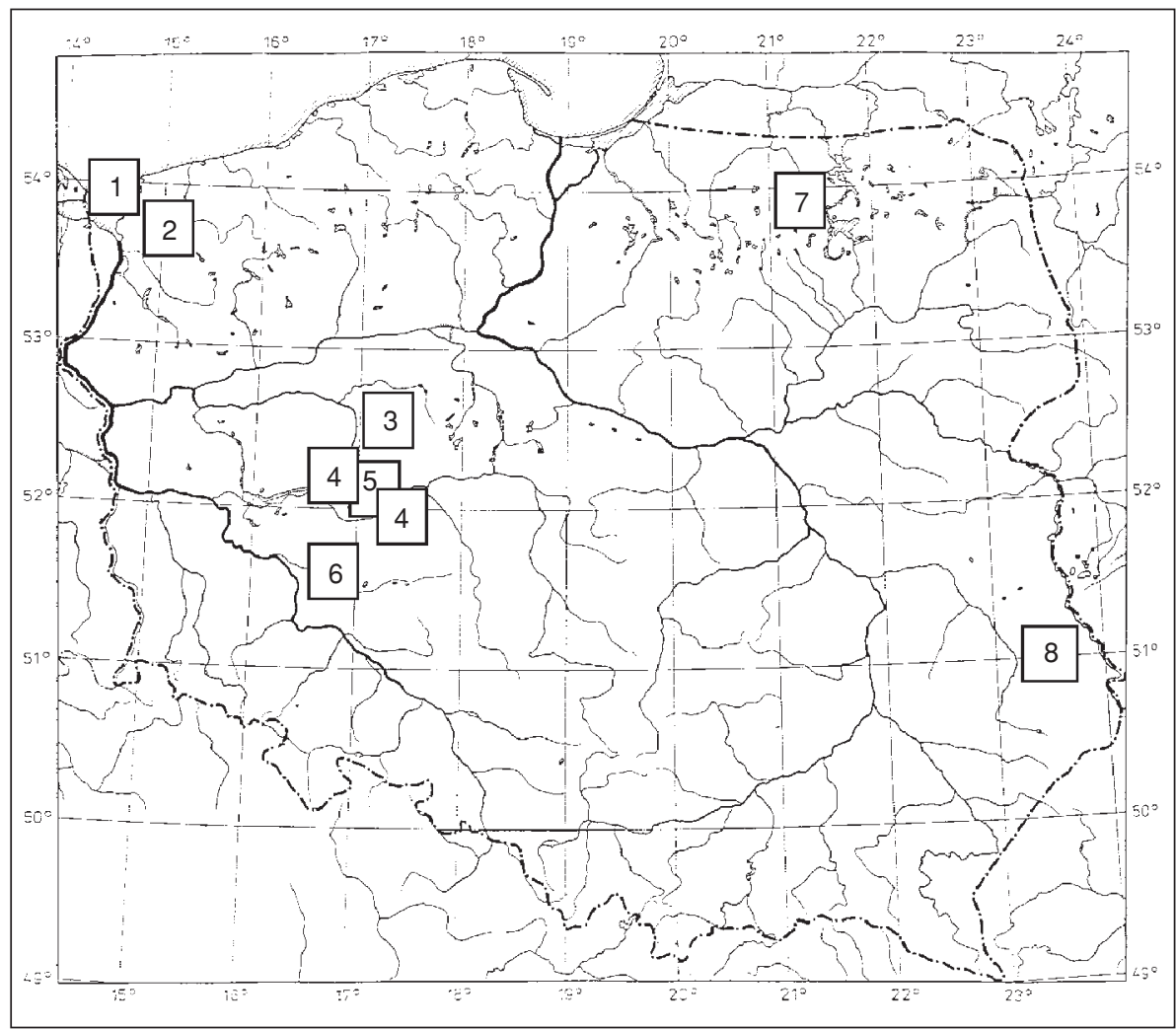

Fig. 1. Distribution of sampling sites: 1 Wolin NP.; 2 - Nowogard FD; 3 Łopuchówko FD; 4 - Wielkopolska NP; 5 Babki FD; 6 - Karczma Borowa FD; 7 Mrągowo FD; 8 - Chełm FD; (NP - National Park; FD - Forest District). of the conidial stage, mycelium was taken from the upper side of leaves. Samples for light microscope (LM) were prepared with lactophenol. For the scanning electron microscope (SEM), fragments of leaves covered with mycelium were preserved for 24 hours in $3 \%$ glutaraldehyde buffered with $0.1 \mathrm{M}$ sodium cacodylate, and for another 24 hours with $1 \%$ osmium tetroxide, again with $0.1 \mathrm{M}$ sodium cacodylate. Next, the objects were gradually dehydrated in an ethanol series (from 30\% to absolute). Then they were dried in a Critical Point Dryer (Balzers), and were placed on specimen stubs and sputtered with gold in an ionic sputter coater (Balzers). After such preparation, the objects were observed under a scanning electron microscope (Philips, type 515 with DISS).

The results of measurements of conidia, after checking their distribution with the Kolmogorov-Smirnov one-sample test, were subjected to analysis of variance and discriminant analysis. Dimensions of cleistothecia were subjected to analysis of variance, and the significance of differences between sites was checked a posteriori by the Tukey test.

\section{RESULTS}

\section{Conidial stage, cleistothecia and ascospores}

Differences in shape and size of conidia between specimens were found (Table 1). Limoniform conidia (Fig. 2) were produced abundantly on leaves of nursery seedlings in the Wielkopolska NP and the Łopuchówko FD. Oval, subcylindric, and ellipsoid conidia occurred sporadically. The dimensions of conidia from these localities ranged between (22.1-)24.8-42.8 $\mu \mathrm{m} \times 13.8-24.8 \mu \mathrm{m}$, and means ranged between 30.4-38.4 $\mu \mathrm{m} \times 16.3-23.9 \mu \mathrm{m}$. The ratio of length to width $(\mathrm{L} / \mathrm{W})$ ranged from 1.6 to 1.8 . Significant is the fact that limoniform conidia were found nearly exclusively in faveolate mycelium. Moreover, they were present only on leaves with oval patches or with the whole leaf surface covered by mycelium. Conidia collected from other specimens were ellipsoid, subcylindric to cylindric (Fig. 3). In this group, the dimensions ranged between (19.3-)22.1-38.6(-40.0) $\mu \mathrm{m} \times 8.3-19.3 \mu \mathrm{m}$ and values of means between 24.3-33.1 $\mu \mathrm{m}$, while the $\mathrm{L} / \mathrm{W}$ ratio varied from 1.8 to 2.4 .

The dimensions of conidiophores from all specimens were: 30.6-69.0 $\mu \mathrm{m} \times 6.8-9.7 \mu \mathrm{m}$ (means: 48-54 $\mu \mathrm{m} \times$ 7.9-8.3 $\mu \mathrm{m}$ ).

Cleistothecia were found only in the Wielkopolska NP (in a nursery and on a tree growing outside the nursery), and in the Łopuchówko and Chełm FDs (in nurseries). Their diameter reached (93.8-)99.4-138.0(-140.8) on specimens where limoniform conidia were found, and (80.0-)88.3-110(118.7) $\mu \mathrm{m}$ on other specimes. The cleistothecia from the young tree in the Wielkopolska NP, where only ellipsoid and cylindric conidia were found earlier, were significantly $(\mathrm{p} \leq 0.001)$ smaller than those from other specimens, while cleistothecia from the nursery in the Łopuchówko FD (limoniform conidia) were significantly larger than the others. Dimensions of ascospores from these cleistothecia were very uniform: 16.6-19.3(-20.7) $\mu \mathrm{m} \times(9.7-) 11.0 \mu \mathrm{m}$.

On the basis of a discriminant analysis, the conidia from the group of samples containing limoniform conidia proved to be distinct from conidia from other samples. On the basis of length and width, $79.3 \%$ of conidia were properly assigned to the groups distinguished on the basis of shape. In MANOVA, the two groups were significantly $(\mathrm{p} \leq 0.001)$ different with respect to both length $\left(\mathrm{F}_{(1.603)}=52.3\right)$ and width $\left(\mathrm{F}_{(1.603)}=245.1\right)$ of conidia.

The $95 \%$ confidence intervals of length and width of conidia in the two groups are compared in Figure 4.

\section{Mycelium characters and disease symptoms}

Mycelium developed on the upper side of leaves in the form of oval patches or stripes along the veins. Both forms could expand and cover the whole leaf surface after some 
TABLE 1. Site and date of collection of plant material, and characteristics of mycelium and conidia. (Data for samples containing limoniform conidia are shaded.)

\begin{tabular}{|c|c|c|c|c|c|c|c|}
\hline \multirow[b]{2}{*}{ Collection site } & \multirow{2}{*}{$\begin{array}{l}\text { Oak species, age gro- } \\
\text { up, date of collection }\end{array}$} & \multirow{2}{*}{$\begin{array}{l}\text { Mycelium type } \\
\text { and formation } \\
\text { on leaves }\end{array}$} & \multirow{2}{*}{$\begin{array}{l}\text { Leaf } \\
\text { discolo- } \\
\text { ration }\end{array}$} & \multirow[b]{2}{*}{$\begin{array}{l}\text { Shape of co- } \\
\text { nidia }\end{array}$} & \multicolumn{3}{|c|}{ Dimensions of conidia } \\
\hline & & & & & $\begin{array}{l}\text { Length range and mean } \\
\qquad[\mu \mathrm{m}]\end{array}$ & $\begin{array}{l}\text { Width range and mean } \\
\qquad[\mu \mathrm{m}]\end{array}$ & $\begin{array}{l}\text { Length/ } \\
\text { width }\end{array}$ \\
\hline \multirow{2}{*}{ Karczma Borowa FD } & $\begin{array}{l}Q . \text { robur, } \\
\text { young tree, } 11 \text { Jun'03 }\end{array}$ & $\begin{array}{l}\text { felted, stripes } \\
\text { along veins }\end{array}$ & none & $\begin{array}{l}\text { subcylindric, } \\
\text { cylindric }\end{array}$ & $\begin{array}{c}24.8-38.6 \\
\mathbf{3 1 . 1}\end{array}$ & $\begin{array}{c}(8.2-) 11.0-16.5 \\
\mathbf{1 2 . 5}\end{array}$ & 2.4 \\
\hline & $\begin{array}{l}Q . \text { robur, } \\
\text { young tree, } 30 \text { Jun'03 }\end{array}$ & $\begin{array}{l}\text { felted, stripes } \\
\text { along veins }\end{array}$ & none & cylindric & $\begin{array}{c}(22.8-) 24.8-35.4 \\
\mathbf{2 9 . 7}\end{array}$ & $\begin{array}{c}11.0-14 . \\
\mathbf{1 3 . 0}\end{array}$ & 2.3 \\
\hline \multirow[t]{2}{*}{ Wolin NP } & $\begin{array}{l}Q \cdot \text { petraea, } \\
\text { young tree, } 24 \text { Jun'03 }\end{array}$ & $\begin{array}{l}\text { faveolate, } \\
\text { oval patches }\end{array}$ & none & $\begin{array}{l}\text { ellipsoid, } \\
\text { subcylindric, } \\
\text { cylindric }\end{array}$ & $\begin{array}{c}27.6-38.6 \\
\mathbf{3 3 . 1}\end{array}$ & $\begin{array}{c}13.8-19.3 \\
\mathbf{1 6 . 6}\end{array}$ & 2.0 \\
\hline & $\begin{array}{l}Q . \text { petraea, } \\
\text { seedling, } 1 \text { Aug'03 }\end{array}$ & $\begin{array}{l}\text { mealy (slightly) } \\
\text { along veins }\end{array}$ & none & $\begin{array}{l}\text { ellipsoid, } \\
\text { subcylindric }\end{array}$ & $\begin{array}{c}26.2-35.9 \\
\text { 31.6 }\end{array}$ & $\begin{array}{c}13.8-15.2 \\
\mathbf{1 4 . 3}\end{array}$ & 2.2 \\
\hline \multirow[t]{7}{*}{ Wielkopolska NP } & $\begin{array}{l}Q \cdot \text { petraea, } \\
\text { seedling, } 1 \text { Jul'03 }\end{array}$ & $\begin{array}{l}\text { floccose, } \\
\text { oval patches }\end{array}$ & yellow & $\begin{array}{l}\text { limoniform, } \\
\text { oval }\end{array}$ & $\begin{array}{c}(27.6-) 30.4-41.4 \\
\mathbf{3 5 . 8}\end{array}$ & $\begin{array}{c}16.6-22.8 \\
\mathbf{1 9 . 6}\end{array}$ & 1.8 \\
\hline & $\begin{array}{l}Q \cdot \text { petraea, } \\
\text { seedling, } 3 \text { Jul'03 }\end{array}$ & $\begin{array}{l}\text { floccose, } \\
\text { oval patches }\end{array}$ & yellow & $\begin{array}{l}\text { limoniform, } \\
\text { ellipsoid }\end{array}$ & $\begin{array}{c}(30.4-) 33.1-42.8 \\
\mathbf{3 8 . 4}\end{array}$ & $\begin{array}{c}22.1-24.8 \\
\mathbf{2 3 . 9}\end{array}$ & 1.6 \\
\hline & $\begin{array}{l}\text { Q. petraea, } \\
\text { seedling*, } 5 \text { Aug'03 }\end{array}$ & $\begin{array}{l}\text { felted, } \\
\text { whole surface }\end{array}$ & brownish & ellipsoid & $\begin{array}{c}27.6-33.1(-38.6) \\
\mathbf{3 1 . 8}\end{array}$ & $\begin{array}{c}12.4-17.9 \\
\mathbf{1 4 . 8}\end{array}$ & 2.1 \\
\hline & $\begin{array}{l}\text { Q. petraea, } \\
\text { seedling, } 13 \text { Aug'03 }\end{array}$ & $\begin{array}{l}\text { felted, } \\
\text { whole surface }\end{array}$ & brownish & $\begin{array}{l}\text { limoniform, } \\
\text { ellipsoid }\end{array}$ & $\begin{array}{c}27.6-35.9 \\
\mathbf{3 1 . 2}\end{array}$ & $\begin{array}{c}16.6-19.3 \\
\mathbf{1 8 . 2}\end{array}$ & 1.7 \\
\hline & $\begin{array}{l}\text { Q.petraea, } \\
\text { seedling*, } 14 \text { Aug'03 }\end{array}$ & $\begin{array}{l}\text { floccose, } \\
\text { oval patches }\end{array}$ & yellow & $\begin{array}{l}\text { limoniform, } \\
\text { ellipsoid }\end{array}$ & $\begin{array}{c}27.6-38.6(-41.4) \\
\mathbf{3 3 . 2}\end{array}$ & $\begin{array}{l}15.2-22.1 \\
\mathbf{1 9 . 5}\end{array}$ & 1.7 \\
\hline & $\begin{array}{l}Q . \text { petraea, } \\
\text { seedling, } 26 \text { Aug'03 }\end{array}$ & $\begin{array}{l}\text { floccose, } \\
\text { oval patches }\end{array}$ & yellow & $\begin{array}{l}\text { limoniform, } \\
\text { ellipsoid }\end{array}$ & $\begin{array}{c}(22.1-) 24.8-38.6 \\
\mathbf{3 0 . 4}\end{array}$ & $\begin{array}{c}13.8-19.3 \\
\mathbf{1 6 . 3}\end{array}$ & 1.8 \\
\hline & $\begin{array}{l}\text { Q. robur, } \\
\text { young tree, } 26 \text { Aug'03 }\end{array}$ & $\begin{array}{l}\text { felted, } \\
\text { along veins }\end{array}$ & $\begin{array}{l}\text { none } \\
\text { or yellowish }\end{array}$ & subcylindric & $\begin{array}{c}24.8-33.1(-35.9) \\
\mathbf{2 8 . 4}\end{array}$ & $\begin{array}{l}11.0-16.6 \\
\mathbf{1 3 . 2}\end{array}$ & 2.1 \\
\hline Nowogard FD & $\begin{array}{l}Q . \text { robur, } \\
\text { young tree, } 22 \text { Jul'03 }\end{array}$ & $\begin{array}{l}\text { faveolate, } \\
\text { oval patches }\end{array}$ & none & $\begin{array}{l}\text { cylindric, } \\
\text { subcylindric, } \\
\text { ellipsoid }\end{array}$ & $\begin{array}{c}(22.1-) 27.6-35.9(-40.0) \\
\mathbf{3 0 . 6}\end{array}$ & $\begin{array}{c}12.4-16.6 \\
\mathbf{1 4 . 2}\end{array}$ & 2.1 \\
\hline Babki FD & $\begin{array}{l}\text { Q. robur, } \\
\text { young tree, } 7 \text { Aug'03 }\end{array}$ & $\begin{array}{l}\text { floccose, } \\
\text { oval patches }\end{array}$ & brownish & $\begin{array}{l}\text { subcylindric, } \\
\text { ellipsoid }\end{array}$ & $\begin{array}{c}24.8-35.9(-40.0) \\
\mathbf{3 0 . 5}\end{array}$ & $\begin{array}{c}12.4-15.2 \\
\mathbf{1 3 . 9}\end{array}$ & 2.2 \\
\hline Mrągowo FD & $\begin{array}{l}Q . \text { petraea, } \\
\text { young tree, } 14 \text { Aug'03 }\end{array}$ & $\begin{array}{l}\text { felted, } \\
\text { whole surface }\end{array}$ & brownish & subcylindric & $\begin{array}{c}22.1-33.1 \\
\mathbf{2 4 . 3}\end{array}$ & $\begin{array}{c}8.3-16.6 \\
\mathbf{1 3 . 8}\end{array}$ & 1.9 \\
\hline Łopuchówko FD & $\begin{array}{l}\text { Q.petraea, } \\
\text { seedling, } 17 \text { Sep'03 }\end{array}$ & $\begin{array}{l}\text { felted, } \\
\text { oval patches }\end{array}$ & yellow & $\begin{array}{l}\text { limoniform, } \\
\text { subcylindric }\end{array}$ & $\begin{array}{c}(24.8-) 27.6-33.1(-35.9) \\
\text { 30.4 }\end{array}$ & $\begin{array}{c}16.6-19.3 \\
\mathbf{1 8 . 2}\end{array}$ & 1.7 \\
\hline Chełm FD & $\begin{array}{l}\text { Q. petraea, } \\
\text { seedling, } 22 \text { Aug'03 }\end{array}$ & $\begin{array}{l}\text { felted, } \\
\text { whole surface }\end{array}$ & yellow & $\begin{array}{l}\text { subcylindric, } \\
\text { ellipsoid }\end{array}$ & $\begin{array}{c}(20.7-) 24.8-37.3 \\
\mathbf{2 8 . 3}\end{array}$ & $\begin{array}{c}12.4-13.8(-16.6) \\
\mathbf{1 3 . 4}\end{array}$ & 2.1 \\
\hline
\end{tabular}

* these two seedlings seemed uninfected during collection, but symptoms appeared after a few days of growth in laboratory conditions; NP - National Park; FD - Forest District

time (Table 1). Yellow or brownish discoloration of leaf tissues was observed on the lower side of the leaf, under the mycelium.
The mycelium appeared in three forms: (1) floccose or felted oval patches (always with yellow or brown discoloration), (2) faveolate oval patches (often with yellow or 


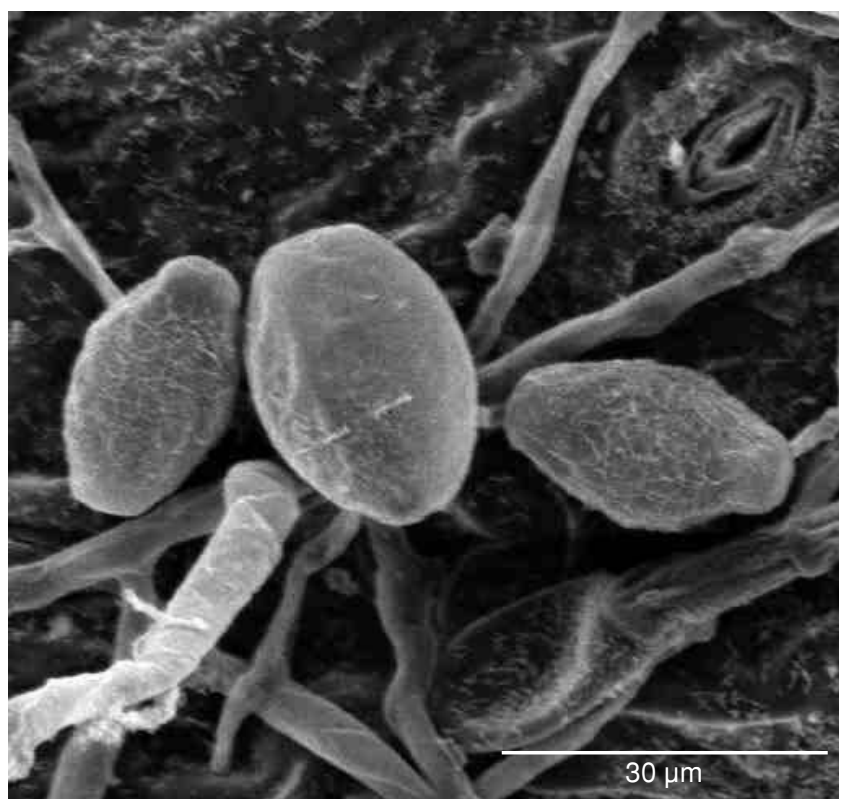

Fig. 2. Limoniform and ellipsoid conidia from a $Q$. petraea seedling from a nursery in the Wielkopolska NP (SEM).

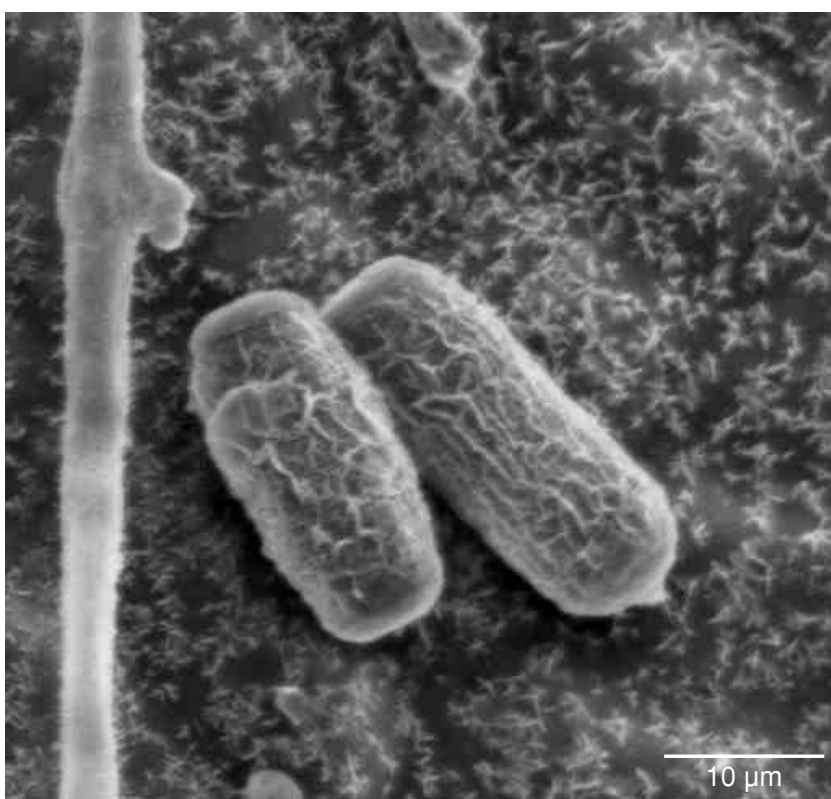

Fig. 3. Cylindric conidia from a young tree of $Q$. robur from the Karczma Borowa FD (SEM).
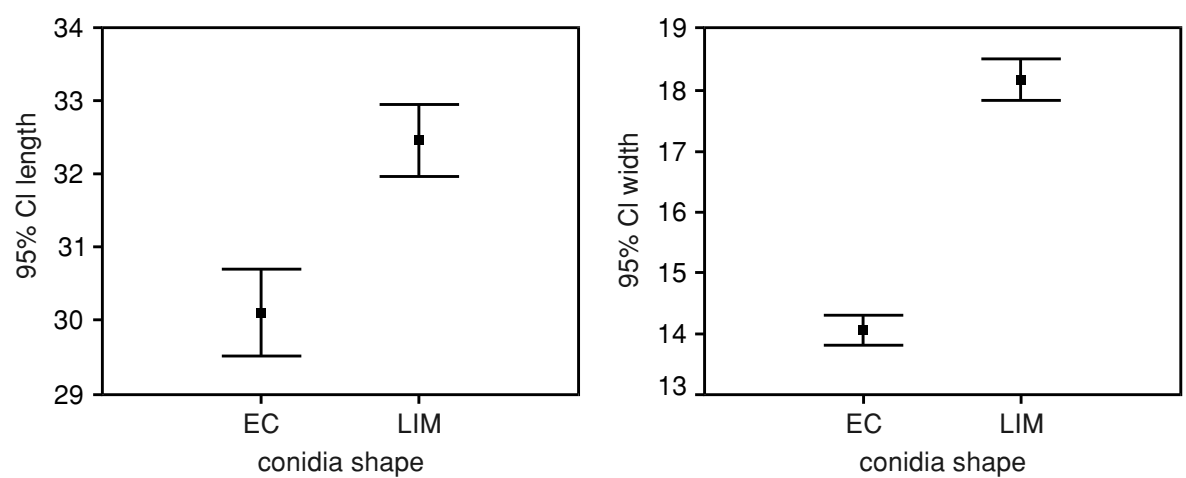

Fig. 4. The $95 \%$ confidence intervals of length and width of conidia in two groups of samples: those containing limoniform conidia (LIM, N=298) and those containing only conidia of ellipsoid to cylindric shapes (EC, $\mathrm{N}=306$ ). brown discoloration), and (3) felted or mealy mycelium along veins (rarely with discoloration). The occurrence of individual forms did not seem to be related to oak species or age group. However, mycelium without limoniform conidia appeared in all three forms listed above, while mycelium with limoniform conidia appeared only in form (1).

\section{DISCUSSION}

Dimensions of conidia and cleistothecia from all specimens were generally consistent with those given in keys for Microsphaera alphitoides. In our study the conidia collected from the lower side of leaves were not considered. Thus we are not able to conclude on occurrence of $M$. hypophylla in Poland. However, due to the great variability (Table 2) of dimensions given in synopses, sometimes it is not easy to distinguish between these two species. Speer (1975), Zahorovska (1988) and Braun (1995) suggested that the taxonomic position of $M$. hypophylla is controversial and $M$. hypophylla could be a synonym of $M$. alphitoides.

However, the limoniform shape of conidia, characteristic of two sites, has not been found in available synopses (Sałata 1985; Braun 1995; Butin 1995; Mańka 1998). The only exception are the works by Zahorovska $(1985,1988)$.
It is possible that the imprecise Czech term vasovity (vaseshaped) used by that author (Zahorowska 1988) to describe one form of conidia of this species observed in Slovakia, is equivalent to the English term limoniform used in our work. Nevertheless, the high L/W ratio $(\geq 1.9)$ suggests that most of the conidia found by that author were ellipsoid, subcylindric or cylindric. In the key on powdery mildews of Europe by Braun (1995), limoniform conidia were noted for $M$. platani (Table 2). Also his description of mycelium in that species is consistent with our observations of the specimens with limoniform conidia. However, that species has been observed so far only on Platanus species. After division of the measured samples into two groups; those containing limoniform conidia and those containing only conidia of other shapes, we found that these groups are significantly different from each other. Conidia from the first group were longer and much wider than the ellipsoid-cylindric type. The L/W ratio was up to 1.8 for the conidia of the limoniform group and always higher than 1.8 for the second conidia group. It must be noted that in the limoniform group, some conidia were ellipsoid, subcylindric, or oval and they were also measured and taken into account when calculating the mean values for this group.

Limoniform conidia were found only in two of the four studied forest nurseries. We could not find it in other locations, even on trees with symptoms of powdery mildew, 
TABLE 2. Comparison of original and published data on dimensions of conidia and cleistothecia of Microsphaera alphitoides (Ma), Microsphaera hypophylla $(\mathrm{Mh})$ and Microsphaera platani $(\mathrm{Mp})$.

\begin{tabular}{|c|c|c|}
\hline Source and conidia shape & $\begin{array}{l}\text { Conidia: dimensions }[\mu \mathrm{m}] \\
\text { LW ratio }\end{array}$ & Cleistothecia: diameter $[\mu \mathrm{m}]$ \\
\hline $\begin{array}{l}\text { Original data: } \\
\text { limoniform, rarely oval or ellipsoid }\end{array}$ & $\begin{array}{c}(22.1-) 24.8-42.8 \times 13.8-24.8 \\
\text { L/W: } 1.6-1.8\end{array}$ & $(93.8-) 99.4-138.0(-140.8)$ \\
\hline $\begin{array}{l}\text { Original data: } \\
\text { ellipsoid to cylindric }\end{array}$ & $\begin{array}{c}(19.3-) 22.1-38.6(-40.0) \times 8.3-19.3 \\
\text { L/W: } 1.8-2.4\end{array}$ & (80.0-) 88.3-110(-118.7) \\
\hline $\begin{array}{l}\text { Sałata }(1985)(M a) \\
\text { ellipsoid, cylindric-ellipsoid }\end{array}$ & $(21-) 31-33(-37) \times(11-) 15-20(-26)$ & (84-)100-121(-147) \\
\hline $\begin{array}{l}\text { Sałata }(1985)(M h) \\
\text { oblong, subcylindric }\end{array}$ & $(21-) 35-46(-56) \times(11-) 13-16(-19)$ & $(90-) 110-128(-162)$ \\
\hline $\begin{array}{l}\text { Braun (1995) }(M a) \\
\text { ellipsoid-ovoid to doliiform, rarely subcylindric }\end{array}$ & $\begin{array}{c}25-40 \times 13-23 \\
\mathrm{~L} / \mathrm{W}: 1.4-2.3(<2)\end{array}$ & $70-150$ \\
\hline $\begin{array}{l}\text { Braun (1995) }(M h) \\
\text { Cylindric (-ellipsoid), with rounded ends }\end{array}$ & $\begin{array}{c}30-45(-65) \times 12-17.5(-18.5) \\
\mathrm{L} / \mathrm{W}: 2.3-3.3\end{array}$ & $(70-) 80-140(-155)$ \\
\hline $\begin{array}{l}\text { Braun (1995) }(M p) \\
\text { ellipsoid (-ovoid) to doliiform, oblong }\end{array}$ & $25-50 \times 14-22.5$ & $80-115$ \\
\hline $\begin{array}{l}\text { Butin } 1995(M a) \\
\text { doliiform }\end{array}$ & $30-36 \times 19-23$ & 100 \\
\hline $\begin{array}{l}\text { Speer (1975) }(M a) \\
\text { ellipsoid, doliiform, ellipsoid-ovoid to doliiform }\end{array}$ & $(23-) 27-39(-48) \times(12-) 14-20(-23)$ & $74-142$ \\
\hline $\begin{array}{l}\text { Zahorovska (1988) }(M a) \\
\text { ellipsoid, doliiform, cylindric, vase-shaped }\end{array}$ & $\begin{array}{c}28-37 \times 11-19 \\
\mathrm{~L} / \mathrm{W}:(1.9-) 2.0-2.2(-2.5)\end{array}$ & $77-124$ \\
\hline
\end{tabular}

growing in the neighbourhood of the nursery with limoniform conidia, no such conidia were observed.

We observed a great variety of forms of mycelium on leaves. A similar variety of forms of $M$. alphitoides mycelium was described by Speer (1975). Mycelium without limoniform conidia appeared in all the distinguished forms, while mycelium with limoniform conidia appeared only in the form of patches, always causing leaf discoloration. In the first case, observed differences of disease symptoms could be related to age of plants or their individual resistance.

More research is needed to answer the question what is the taxonomic position of oak powdery mildew with limoniform conidia.

\section{ACKNOWLEDGEMENTS}

This study was supported by the Institute of Dendrology, Polish Academy of Sciences. The authors thank Dr. K. Idzikowska from the Laboratory of Electron Microscopy, Faculty of Biology, A. Mickiewicz University for help in SEM studies and M. Ratajczak for help in collection of plant material.

\section{LITERATURE CITED}

AYRES P.G. 1976. Natural resistance to Oak mildew. Arboricultural J. 3: 23-29.

BRAUN U. 1995. The powdery mildews (Erysiphales) of Europe. Gustav Fischer, Jena-Stuttgart-New York, pp. 289.

BUTIN H. 1995. Tree Diseases and Disorders. Oxford University Press, Oxford-New York-Tokyo, pp. 252.

MAŃKA K. 1998. Fitopatologia. PWRiL, Warszawa, pp. 368.

SAŁATA B. 1985. Flora Polska. Rośliny Zarodnikowe Polski i Ziem Ościennych. Grzyby (Mycota) Tom XV. Workowce (Ascomycetes). Mączniakowe (Erysiphales). PWN, Warszawa-Kraków, pp. 247. (in Polish)

SPEER E.O. 1975. Untersuchungen zur Morphologie und Systematik der Erysiphaceen. Der Eichenmehltau Microsphaera alphitoides Griff. et Maubl. Sydowia 27: 112-126.

THOMAS F.M., BLANK R., HARTMANN G. 2002. Abiotic and biotic factors and their interactions as causes of oak decline in Central Europe. Forest Pathol. 32 (4-5): 277-307.

ZAHOROVSKA E. 1985. Germination of the conidia of the fungus Microsphaera alphitoides. Acta Fac. Rer. Natur. Univ. Comenianae Bot., 32: 77-84.

ZAHOROVSKA E. 1988. Paraziticka huba Microsphaera a jej askokarpove stadium na duboch Slovenska. Ceska Mykologie 42, 3: 149-157. (in Czech with English summary) 